\title{
Evaluation of accuracy of invasive and non-invasive blood pressure monitoring in relation to carotid artery pressure in anaesthetised ponies
}

\author{
Thomas C. Gent', Andrea. Schwarz', Lea Annina Hatz', Miguel Gozalo-Marcilla², Stijn Schauvliege², Frank Gasthuysªnd Regula \\ Bettschart-Wolfensberger ${ }^{?}$ \\ 1 Section of Anaesthesiology, Equine Department, Vetsuisse Faculty, University of Zurich, Zurich, Switzerland \\ 2 Department of Surgery and Anaesthesiology of Domestic Animals, Faculty of Veterinary Medicine, University of Gent, Merelbeke, Belgium
}

\begin{abstract}
Summary: Invasive blood pressure measurement (IBP) using peripheral arteries is a commonly used technique in equine anaesthesia, although the accuracy has not been demonstrated. Non-invasive blood pressure monitoring (NIBP) may be indicated for field anaesthesia, short procedures and foal anaesthesia. In the present report, the agreement of various IBP and NIBP measuring sites compared to carotid artery pressure was tested in anaesthetised experimental ponies. Six ponies were anaesthetised in lateral recumbency with sevoflurane and received either saline or dexmedetomidine boli followed by constant rate infusion (CRI). Invasive blood pressure measurements were obtained simultaneously from the carotid, facial and metatarsal arteries. NIBP measurements over both median arteries, metatarsal and middle coccygeal arteries were performed in random order. All blood pressure readings obtained were compared to carotid pressure by BlandAltman analysis. Non-invasive blood pressure measurements had larger bias and poorer limits of agreement compared to IBP measurements. NIBP measurement from the coccygeal artery had the best repeatability and best limits of agreement of all NIBP positions and was not affected by the use of dexmedetomidine. The facial artery had smaller limits of agreement with dexmedetomidine treatment. There was no difference between the facial and metatarsal arteries during dexmedetomidine treatment in MAP and DAP. Systolic arterial pressures from the metatarsal artery showed larger bias and larger limits of agreement compared to facial artery. In conclusion, NIBP measurement from the tail artery is a reliable alternative to direct arterial blood pressure measurement. Both the metatarsal and facial arteries have acceptable agreement with carotid artery pressure so the choice can be based on the logistics of the procedure.
\end{abstract}

Keywords: Anaesthesia / Dexmedetomidine / Equine / Blood Pressure / Monitoring

Vergleich der Genauigkeit einer invasiven und nicht-invasiven peripheren Blutdruckmessung zum Karotisdruck bei anästhesierten Ponies

In vielen Pferdekliniken gehört die invasive Messung des arteriellen Blutdruckes (IBP) mittels Katheter in peripheren Arterien während einer Pferdeanästhesie zur Standardüberwachung der Anästhesie, obwohl die Genavigkeit dieser Messung nie belegt wurde. Nichtinvasive Blutdruckmessung ist eine mögliche Alternative für Feldanästhesien, kurze Eingriffe oder bei Fohlen. In der voliegenden Studie wurde die Übereinstimmung von an verschiedenen Stellen invasiv und nichtinvasiv gemessenen Blutdrücken mit dem Blutdruck in der Arteria Karotis bei unter experimentellen Bedingungen anästhesierten Ponis bestimmt. Sechs Ponis wurden in Seitenlage mit Sevofluranästhesie anästhesiert und erhielten zusätzlich Kochsalzlösung oder Dexmedetomidin Boli gefolgt von einer kontinuierlichen Infusion. Der invasive Blutdruck wurde gleichzeitig in der Arteria f., der A. metatarsalis und der A. karotis gemessen. Nicht invasive Blutdruckmessungen über der Schweifarterie, den beiden Medianarterien oder der Metatarsalarterie wurden in zufälliger Reihenfolge nacheinander vorgenommen. Alle gemessenen Blutdrucke wurden mit den zur gleichen Zeit in der A. karotis gemessenen Werten mittels Bland Altman-Analyse verglichen. Die nicht invasiven Messungen zeigten größere systematische Messabweichungen und geringere Übereinstimmung als die invasiven Messungen. Bei den nicht invasiven Messungen zeigte die Messung über der Schweifarterie die beste Übereinstimmung bei wiederholten Messwerten und auch die beste Übereinstimmung mit dem Karotisdruck insgesamt und wurde nicht durch die Applikation von Dexmedetomidin beeinflusst. Die Messung in $\operatorname{der}$ A. fazialis zeigte eine bessere Übereinstimmung während Dexmedetomidininfusion. Während Dexmedetomidininfusion gab es bezüglich mittlerem und diastolischen arteriellem Blutdruck in der A. fazialis und den Metatarsalarterien keinen Unterschied. Die systolischen Blutdrücke, welche in der A. metatarsalis gemessen wurden hingegen zeigten größere systematische Messabweichungen und eine geringere Übereinstimmung als diejenigen, welche in der A. fazialis gemessen wurden. Zusammenfassend muss gefolgert werden, dass die nicht invasive Blutdruckmessung über der Schweifarterie für die Pferdepraxis eine verlässliche Alternative zur invasiven Blutdruckmessung darstellt. Sowohl die Blutdruckmessungen in der Metatarsal- als auch in der Fazialarterie zeigten eine akzeptable Übereinstimmung mit der Blutdruckmessung in der A. karotis und können beide verwendet werden, je nachdem wo operiert wird.

Schlüsselwörter: Anästhesie / Dexmedetomidin / Pferde / Blutdruck / Überwachung

Citation: Gent T. C., Schwarz A., Hatz L. A., Gozalo-Marcilla M., Schauvliege S., Gasthuys F., Bettschart-Wolfensberger R. (2015) Evaluation of accuracy of invasive and non-invasive blood pressure monitoring in relation to carotid artery pressure in anaesthetised ponies. Pferdeheilkunde 31, 33-38

Correspondence: Dr. Thom Gent, Section Anaesthaesiology, Equine Department, Vetsuisse Faculty, Winterthurerstrasse 260, Zürich 8057, Switzerland. E-mail: tgent@vetclinics.uzh.ch

\section{Introduction}

The risk of mortality during anaesthesia in horses is significantly higher compared to human and other veterinary species (Johnston 2005). One third of all equine anaesthetic related deaths have been demonstrated to be due to cardiovascular problems (Gent and Bettschart-Wolfensberger 2013). Invasive blood pressure (IBP) monitoring is a commonly used technique in equine anaesthesia and together 
with heart rate and interpretation of mucous membranes is most often the only method of evaluatiing cardiovascular function in the clinical setting. This technique is frequently preferred to non-invasive methods since it is a direct measurement, gives a continuous reading and is considered to be more accurate than NIBP. Peripheral arteries including the facial and the metatarsal artery are used for IBP measurement even though in cases of reduced or increased peripheral vascular resistance, pressures might differ substantially from central arterial pressure. Placement of an arterial catheter in equine patients is not without risk. Sesamoid osteitis (Barr et al. 2005) and flexor tendon sepsis (Schneider et al. 1992) have been reported as a result of metatarsal artery catheterisation. Furthermore, arterial access may be difficult especially in cardiovascularly compromised equine patients. For field anaesthesia, short procedures or in neonates reliable alternatives to IBP measurement are desirable. The $\alpha 2$-adrenoreceptor agonist dexmedetomidine is commonly used in small animal anaesthesia and is gaining popularity in equine anaesthesia (Marcilla et al. 2012). The majority of horses undergoing general anaesthesia are sedated with an $\alpha 2$-agonist prior to anaesthesia induction and balanced anaesthesia including $\alpha 2$-agonists is gaining widespread popularity (Kalchofner et al. 2006, Ringer et al. 2007, Gozalo-Marcilla et al. 2013). The main cardiovascular effect of $\alpha 2$-adrenoreceptor agonists is vasoconstriction, which may alter the accuracy of blood pressure monitoring devices.

The aim of this investigation was to determine the agreement of various invasive and non-invasive blood pressure measuring sites against carotid artery pressure and to investigate the influence of dexmedetomidine on these measurements.

\section{Materials and Methods}

All ponies were anaesthetised as part of a parallel investigation into the sevoflurane MAC sparing effects of dexmedetomidine.

\section{Animals}

Six healthy ponies ( 5 geldings and 1 mare) aged $12.7 \pm 2.8$ years and weighing $294 \pm 51 \mathrm{~kg}$, were used. The left carotid artery had previously been transposed to a subcutaneous position.

\section{Instrumentation}

Detailed methods of instrumentation have previously been published (Gozalo-Marcilla et al. 2012). Intravenous access was secured via the left jugular vein and anaesthesia induced with $5 \%$ sevoflurane in oxygen delivered by nasotracheal tube. Following induction of anaesthesia, the ponies were placed in right lateral recumbency on a padded surgical table and anaesthesia maintained with sevoflurane $\left(F_{E}^{\prime} 2.5 \%\right)$ in oxygen and air $\left(\mathrm{FiO}_{2} 55 \%\right)$. Ventilation was adjusted to $\mathrm{PaCO}_{2} 50-60 \mathrm{mmHg}$. Ringer Lactate Solution was given at $3 \mathrm{ml} / \mathrm{kg} / \mathrm{hr}$ throughout and a urinary catheter placed at the start. A water warming blanket was placed beneath all animals and the room temperature maintained at $23^{\circ} \mathrm{C}$.
Twenty-two gauge 1.5 inch catheters (Venocan) were placed in the transposed left carotid artery, left facial and left metatarsal artery for invasive blood pressure monitoring. Noninvasive blood pressure cuffs (Sentinel, Vetronics, UK), with widths of $40-60 \%$ of the diameter of the limb, were placed over the middle coccygeal artery close to the tail base, the right metatarsal artery and both metacarpal arteries all at the mid-level of the cannon bone, with the legs in a horizontal position. Catheters were connected by $1 \mathrm{~m}$ non-compliant tube to blood pressure transducers (Transpac, ICU Medical), which were then connected to constant pressure flush bags. Transducers were zeroed at the level of the sternum during lateral recumbency and invasive blood pressures measured continuously with a Datex Ohmeda S-5 monitor. Non-invasive blood pressure was measured by oscillometry - Sentinel Veterinary Blood Pressure Monitoring System (Vetronic, UK) at the different sites in random order.

Dobutamine was infused to maintain MAP above $65 \mathrm{mmHg}$ if it fell below $60 \mathrm{mmHg}$ (measured via carotid artery). $\mathrm{FiO}_{2}$ was increased if $\mathrm{PaO}_{2}$ fell below $60 \mathrm{mmHg}$ as determined by blood gas analysis. At the end of anaesthesia, all animals received a bolus of dexmedetomidine $\left(0.875 \mu \mathrm{g} \mathrm{kg}^{-1}\right)$ and were transported to a padded recovery box. The endotracheal tube was removed when swallowing was observed. Manual support of the tail was given to aid recovery.

\section{Experimental Design}

Each pony was anaesthetised twice and received either saline or dexmedetomidine with a 3-week washout between. The order of treatments was randomized. Following instrumentation a 10-minute baseline was established and then a bolus of dexmedetomidine $(3.5 \mu \mathrm{g} / \mathrm{kg})$ or equivalent volume saline administered over 5 minutes. Afterwards either dexmedetomidine $(1.75 \mu \mathrm{g} / \mathrm{kg} / \mathrm{hr})$ or equivalent volume saline was infused as a CRI.

Invasive blood pressures at all three sites were continuously monitored throughout anaesthesia and recorded at the start of the baseline period and thereafter together with each NIBP measurement. NIBP measurements at the different sites were performed in random order all once before bolus administration and thereafter one measurement after the other in random order until the end of anaesthesia. For each measurement NIBP site, four separate measurements were taken concurrently with all IBP measurements from the carotid, facial and metatarsal arteries. Non-invasive blood pressure measurements were not performed concurrently at the different sites.

\section{Data Analysis}

Data were pooled and analysed by Bland-Altman comparison of methods (Bland and Altman 1999) including the refinement for replicated paired measurements for an individual. Analysis was performed in Matlab and scripts for analysis were written for this purpose by one of the authors. Data was plotted in Graphpad Prism 5.

Blood pressure measurements from IBP and NIBP sites were taken in replicates of four at various time points. However, 
since the Sentinel may take 30-40s to take a NIBP reading, and given the irregular heart rhythm induced by dexmedetomidine, each pair of recordings was treated as a separate time point. However due to the potential for inter-individual variability, all measurements from each experiment were pooled. The differing time points were assumed to have differing blood pressure values, since in some instances a bolus of dexmedetomidine was given, likely to produce a transient vasoconstriction.

Data for saline and dexmedetomidine treatments were analysed as separate groups. In order to compare blood pressure measuring techniques, all measurements were evaluated with respect to measurements from the carotid, which was considered the gold standard. The bias was calculated as the mean of the differences between two measurements and shows whether the value over or under-estimates the carotid pressure. The limits of agreement were calculated as 1.96 times the standard deviation of the differences between the paired recordings and indicates the variability.

The subject mean was plotted against the mean difference in method observations. Assessment of the effect of measurement magnitude on the difference between measurement methods was made by linear regression of the measurement mean $(x)$ against difference in measurements ( $y$ ). If the slope was significantly non-zero at $95 \%$ significance as determined by F-test, then the magnitude of the measurement was deemed to affect the difference in measurement. Comparison of ranges of blood pressure measurement were analysed by one-way ANOVA with post-hoc Tukeys modification.

In order to investigate the possible cause in the differences of agreement between measurement methods, the repeatability for each method was calculated since poor repeatability of measurements can lead to a poor agreement between methods (Bland and Altman 1999). The coefficient of repeatability was calculated from all pairs of measurements as twice the standard deviation of the differences squared.

\section{Results}

From the six ponies used in the experiment, all six received the dexmedetomidine protocol while only five were used for the saline protocol. Dobutamine was not required in any of the ponies and all recovered to standing on the first attempt without injury.

Table 1 shows the total number of pairs of measurements recorded at each location and the total number of attempted recordings made for all ponies. When comparing to measurements from the carotid, a total of 729 paired measurements were made from the facial artery (IBP), 720 from the metatarsal artery (IBP), 148 from the right median artery (NIBP), 133 from the left median artery (NIBP), 137 from the right metatarsal artery (NIBP) and 177 from the coccygeal artery (NIBP).

Non-invasive blood pressure measuring devices may not always measure successfully due to factors such as movement artefacts or poor pulse detection. The measurement success rate for NIBP measurement ranged from $73.9 \%$ for the right median artery to $92.3 \%$ for the coccygeal artery. Columns 5 and 6 of table 1 show the average success rate and standard deviation for each recording site for each of saline and dexmedetomidine treatment. The variability was on the part of the individual while no significant difference $(p>0.1)$ was found between saline and dexmedetomidine groups.

Bland-Altman analysis (Figure 1) showed a bias with a linear relationship for all comparisons made. Therefore the magnitude of the measurement did not impact the bias of the measurement. A positive bias indicates an underestimation of the carotid pressure. For invasive blood pressure monitoring, the calculated bias for both the metatarsal (MAP Saline $2.9 \mathrm{mmHg} \pm 16.1$, Dexmedetomidine $4.9 \mathrm{mmHg} \pm 5.2)$ and facial (MAP Saline $0.7 \mathrm{mmHg} \pm 13.0$, Dexmedetomidine 3.3 $\mathrm{mmHg} \pm 7.1)$ arteries were similar, regardless of dexmedetomidine or saline treatment. The facial artery tended to underestimate the systolic blood pressure (bias saline $3.6 \mathrm{mmHg} \pm 15.8$, dexmedetomidine $2.4 \mathrm{mmHg} \pm 6.6$ ), whereas metatarsal and median arteries overestimated the systolic carotid pressure. The MAP and DAP of all invasive blood pressure parameters were underestimates of the carotid blood pressure (positive bias). The limits of agreement for all invasive measurements were smaller during dexmedetomidine treatment, with the exception of systolic metatarsal measurements. For non-invasive blood pressure measurements, dexmedetomidine increased the limits of agreement for MAP. The coccygeal artery had the lowest limits of agreement for both saline

Table 1 - Number of paired arterial blood pressure (IBP and NIBP) recordings from six different recording sites and success rates for the number of attempted recordings. Success rate data are shown as mean \pm standard deviation of all horses tested. There was no significant difference between saline or dexmedetomidine treatments with regard to whether attempted measurements were successful or not ( $p>0.1$ in all cases, Student's T-test). Anzahl invasiver und nichtinvasiver Messungen des arteriellen Blutdruckes an sechs verschiedenen Messorten und die Erfolgsrate im Vergleich zur Anzahl erfolgter Messungen. Die Erfolgsraten wurden über alle getesteten Pferde gemittelt und sind dargestellt als Mittelwert \pm Standardabweichung. Es gab keinen Unterschied bezüglich Erfolgsrate bei Messungen während der Infusion von physiologischer Kochsalzlösung im Vergleich zu Dexmedetomidininfusion ( $p>0.1$ in allen Fällen, Student's T-test).

\begin{tabular}{cccccc}
\hline Measuring Site (artery) & IBP/NIBP & No. Pairs & Success \% & Succ. Sal. \% & Succ. Dex. \% \\
\hline Facial (left) & IBP & $729 / 729$ & 100 & 100 & 100 \\
Metatarsal (left) & IBP & $720 / 720$ & 100 & $57.37 \pm 32.8$ & $70.7 \pm 40.0$ \\
Median (left) & NIBP & $148 / 182$ & 81.3 & $70.0 \pm 41.5$ & $80.7 \pm 20.5$ \\
Median (right) & NIBP & $133 / 180$ & 73.9 & $65 \pm 41.8$ & $81.3 \pm 23.7$ \\
Metatarsal (right) & NIBP & $137 / 180$ & 76.1 & $92.5 \pm 16.9$ & $88.8 \pm 14.0$ \\
Coccygeal & NIBP & $177 / 191$ & 92.3 & 700 \\
\hline
\end{tabular}


Fig. 1 - Summary of the Bland-Altman analysis for two different measuring techniques and six different measuring sites during saline or dexmedetomidine infusion when compared to the carotid artery, A: SAP, B: MAP, C: DAP C

Zusammenfassung der BlandAltman Analyse für zwei verschiedene Messtechniken und sechs verschiedene Messorte während der Infusion von Kochsalzlösung oder Dexmedetomidin im Vergleich zu der Messung in der Karotisarterie, A: SAP, B: MAP, C: DAP
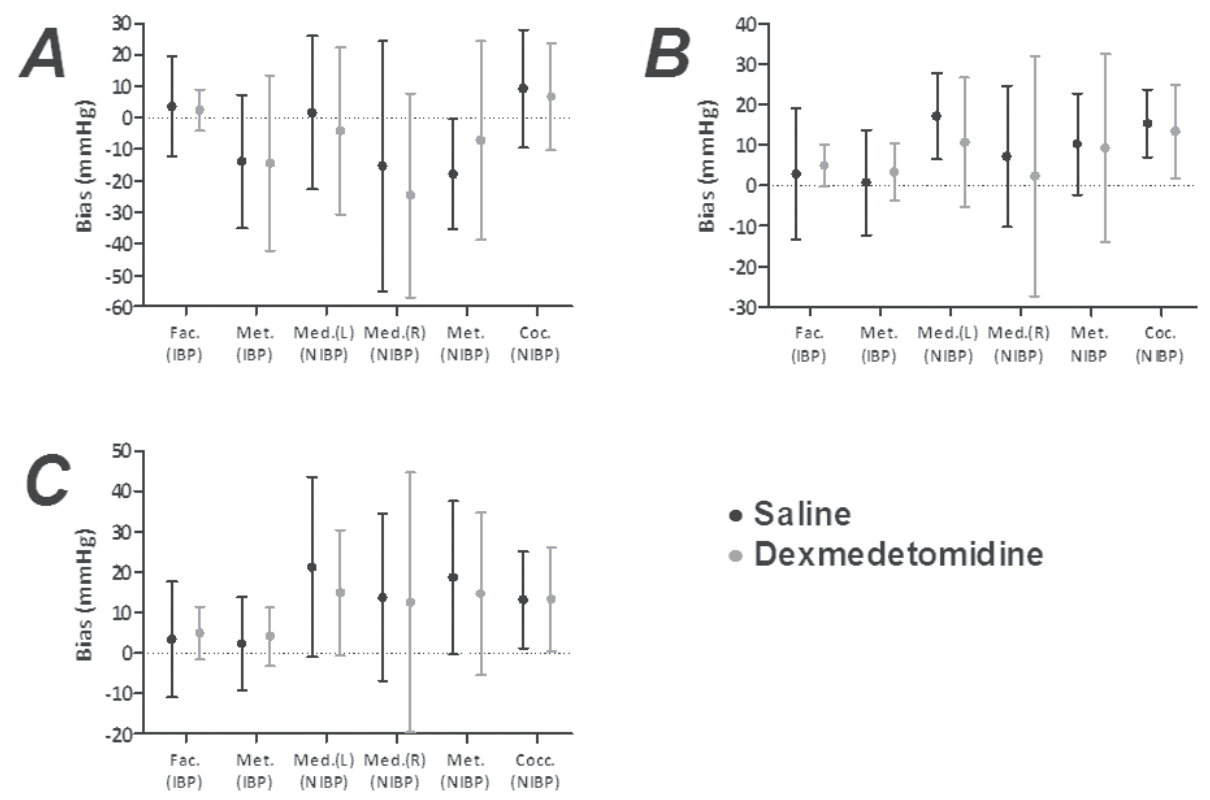

- Saline

- Dexmedetomidine and dexmedetomidine treatment (saline 15.3 \pm 8.2 , dexmedetomidine 13.3 \pm 11.6 ).

Since a reduction in the $95 \%$ limits of agreement could be caused by a reduced range of measurement between the treatment groups, the ranges of blood pressure for the saline and dexmedetomidine groups were additionally investigated. Figure 2 shows the median, $5 \%$ and $95 \%$ quartiles and range of blood pressure measurements by each method for both treatment groups. The median and range of measurements from the carotid artery (in comparison to the other measurement sites) were significantly lower $(p<0.001)$ for the dexmedetomidine group for each of SAP, MAP and DAP. The overall ranges and median measurements for SAP, MAP and DAP were also significantly smaller for dexmedetomidine compared with saline.

The repeatability was calculated for each of the measurement sites. For the IBP measurements, the carotid artery had the best

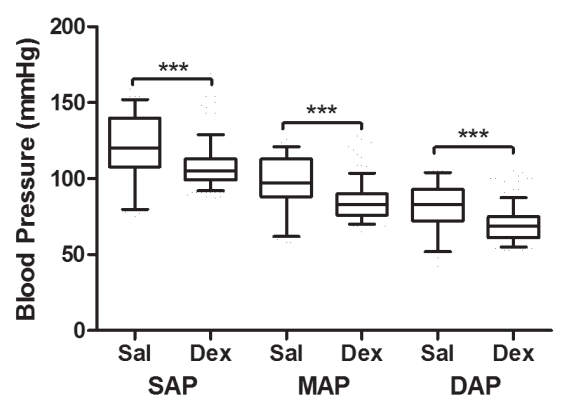

Fig. 2 - Analysis of the median, 5\% and 95\% interquartiles and range for blood pressure measurement from the carotid artery during saline and dexmedetomidine. The medians and ranges were significantly lower for dexmedetomidine treatment for all parameters.

Analyse der Medianwerte, $5 \%$ und $95 \%$ Interquartilen sowie der Spannweite der Blutdrucke der Karotisarterie während der Infusion von Kochsalzlösung oder Dexmedetomidin. Die Medianwerte und Spannweiten sind während der Dexmedetomidininfusion signifikant tiefer als während der Kochsalzinfusion. repeatability for SAP, MAP and DAP. Dexmedetomidine improved the repeatability for all 3 invasive measuring methods for SAP (carotid 10.7\%, facial 20.5\%, metatarsal 16.8\%). For MAP measurements, the facial and metatarsal arteries improved repeatability $(23.1 \%$ and $31.6 \%$ respectively) whereas the carotid reduced repeatability by $74.6 \%$ during dexmedetomidine. Of the non-invasive measuring sites, the tail gave the most reproducible measurements and the repeatability was slightly better with dexmedetomidine (11.9\% increase). Of all non-invasive measuring sites, it was the only one with a comparable MAP repeatability to the carotid artery.

\section{Discussion}

The primary aim of this investigation was to determine the agreement of two IBP measuring sites and four NIBP measuring sites compared to carotid artery pressure using a new oscillometry device during sevoflurane anaesthesia in laterally recumbent ponies and to test the influence of dexmedetomidine infusion. As expected, the agreement of invasive measurement methods was better than with non-invasive methods. However indirect measurement of arterial blood pressure at the coccygeal artery had a lower variability compared to IBP methods.

For IBP, the use of dexmedetomidine CRI resulted in slightly smaller limits of agreement and lower bias, but probably with little clinical consequence. In the metatarsal artery, limits of agreement for SAP increased probably due to vasoconstriction increasing the damping of the pressure waves in a smaller vessel further away from the carotid.

The relatively wide limits of agreement of IBP in comparison to carotid pressure was a surprising result. Especially when considering that this was an experimental study with standardized positioning of the ponies and transducers and no mechanical interference. This variability should be considered when designing future experiments requiring accurate cardiovascular monitoring. 
Another significant finding was that the facial artery had better agreement for blood pressure measurements with the carotid artery, compared to the metatarsal artery. The arterial pulse is amplified as it moves toward the periphery due to wave reflection and the arterial tree. This amplification is characterized mainly by an increased SAP (Muir 1983) as recorded in the present study. Furthermore the facial artery gave more reliable measurements since the repeatability was better than the metatarsal artery. This may be because the facial artery receives its supply directly from the carotid artery and therefore the two are more likely to closely correlate.

In clinical practice $\alpha 2$-adrenoceptor agonists such as romifidine, detomidine, xylazine, medetomidine or dexmedetomidine are given before almost every horse anaesthesia. Furthermore the use of $\alpha 2$-adrenoceptor balanced anaesthesia has recently become popular in equine practice (Kalchofner et al. 2006, Ringer et al. 2007, Devisscher et al. 2010, BettschartWolfensberger et al. 2011, Marcilla et al. 2012) therefore it was considered necessary to test the influence on arterial blood pressure. We have shown in the present study that with dexmedetomidine, NIBP is more variable than IBP. This is probably a consequence of dexmedetomidine induced vasoconstriction, making it more difficult to identify the pulse wave via the cuff. In dogs it has been shown that peripheral vasoconstriction and low cardiac output cause a loss of NIBP signal (Dyson 1997). If $\alpha 2$-adrenoceptor agonists are used before indirect blood pressure measurement, this has to be taken into consideration.

Invasive blood pressure monitoring in horses is widespread but awareness of possible complications and effective time management in practice would possibly favour the use of NIBP monitors. As demonstrated by other investigators (Ellis 1975), indirect measurement of blood pressure from the middle coccygeal artery may either under or overestimate the carotid pressure. Cuff size, one of the most important factors influencing the accuracy of NIBP measurement was carefully chosen according to the manufacturers recommendations. The coccygeal artery yielded the best results of all NIBP cuff positions tested in the present study. Pulse detection, that is known to have a major influence on measurement accuracy of non-invasive devices (Grosenbaugh 1998), was relatively good in the coccygeal artery with a success rate of $92.3 \%$. Despite this, mean limits of agreement for MAP recorded of 15.3 and $13.3 \mathrm{mmHg}$ with saline and dexmedetomidine seem relatively high. The limits of agreement in the present study were also relatively large with IBP measurements, especially when using the metatarsal artery. Guidelines for the measurement of blood pressure in dogs and cats (Brown et al. 2007) recommend that $80 \%$ of measurements should lie within $20 \mathrm{mmHg}$ of the reference method.

In conclusion, the agreement of IBP measuring site is influenced by $\alpha 2$-adrenoceptor agonists and facial artery pressure is closer to carotid artery pressure than metatarsal artery pressure. Non-invasive blood pressure measurements from the tail had the largest overall bias (MAP Saline 15.3 \pm 8.2 $\mathrm{mmHg}$, Dexmedetomidine 13.3 $\pm 11.6 \mathrm{mmHg}$ ) and were an underestimate of the carotid pressure, but with the smallest limits of agreement and the best repeatability. The bias was within limits that are considered acceptable for non-invasive blood pressure measurement in dogs.

\section{Animal Welfare Statement}

The experiment was approved by the Ethical Committee of the Faculty of Veterinary Medicine of the University of Ghent (2011/059).

\section{References}

Barr E. D., Clegg P. D., Senior M. J., Singer E. R. (2005) Destructive lesions of the proximal sesamoid bones as a complication of dorsal metatarsal artery catheterization in three horses. Vet. Surg. 34, 159-166

Bettschart-Wolfensberger R., Dicht S., Vullo C., Frotzler A., Kümmerle J. M., Ringer S. K. (2011) A clinical study on the effect in horses during medetomidine-isoflurane anaesthesia, of butorphanol constant rate infusion on isoflurane requirements, on cardiopulmonary function and on recovery characteristics. Vet. Anaesth. Analg. 38, 186-194

Brown S., Atkins C., Bagley R., Carr A.. Cowgill L., Davidson M., Egner B., Elliott J., Hennik R., Labato M., Littman M., Polzin D., Ross L., Snyder P., Stepien R. (2007) Guidelines for the identification, evaluation, and management of systemic hypertension in dogs and cats. Vet. Int. Med. 21, 542-558

Devisscher L., Schauvliege S., Dewulf J., Gasthuys F. (2010) Romifidine as a constant rate infusion in isoflurane anaesthetized horses: a clinical study. Vet. Anaesth. Analg. 37, 425-433

Dyson D. H. (1997) Assessment of 3 audible monitors during hypotension in anesthetized dogs. Can. Vet. J. 38, 564-566

Ellis P.M. (1975) The indirect measurement of arterial blood pressure in the horse. Equine Vet J 7, 22-26

Gent T. C., Bettschart-Wolfensberger R. (2013) Peri-anaesthetic mortality in horses - the need for CEPEF-4. Vet. Anaesth. Analg. 40, el-2

Gozalo-Marcilla M., Hopster K., Gasthuys F., Hatz L., Krajewski A.E., Schauvliege S. (2012) Effects of a constant-rate infusion of dexmedetomidine on the minimal alveolar concentration of sevoflurane in ponies. Equine Vet. J. 45, 204-208.

Gozalo-Marcilla M., Steblai B., Schauvliege S., Duchateau L., Gasthuys F. (2013) Comparison of the influence of two different constant-rate infusions (dexmedetomidine versus morphine) on anaesthetic requirements, cardiopulmonary function and recovery quality in isoflurane anaesthetized horses. Res. Vet. Sci. 95, 1186-94

Grosenbaugh D. A., Muir W. W. (1998) Accuracy of noninvasive oxyhemoglobin saturation, end-tidal carbon dioxide concentration, and blood pressure monitoring during experimentally induced hypoxemia, hypotension, or hypertension in anesthetized dogs. Am. J. Vet. Res. 59, 205-212

Johnston G. M. (2005) Findings from the CEPEF epidemiological studies into equine perioperative complications. Equine vet. Educ. Manual 7, 64-68

Kalchofner K. S., Ringer S. K., Boller J., Kästner S., Lischer C., Bettschart-Wolfensberger R. (2006) Clinical assessment of anesthesia with isoflurane and medetomidine in 300 equidae. Pferdeheilkunde 22, 301-308

Marcilla M. G., Schauvliege S., Segaert S., Duchateau L., Gasthuys F. (2012) Influence of a constant rate infusion of dexmedetomidine on cardiopulmonary function and recovery quality in isoflurane anaesthetized horses. Vet. Anaesth. Analg. 39, 49-58

Muir W.W., Wade A., Grospitch B. (1983) Automatic noninvasive sphygomanometry in horses. J. Am. Vet. Med. Assoc. 182, 1230- 1233

Ringer S. K., Kalchofner K., Boller J., Fürst A., Besttschart-Wolfensberger R. (2007) A clinical comparison of two anaesthetic protocols using lidocaine or medetomidine in horses. Vet. Anaesth. Analg. 34, 257-268

Schneider R. K., Bramlage L. R., Moore R. M., Mecklenburg L. M., Kohn C. W., Gabel A. A. (1992) A retrospective study of 192 horses affected with septic arthritis/tenosynovitis. Equine Vet. J. 24, $436-442$ 


\section{Erweiterte Zusammenfassung}

Die Überwachung des arteriellen Blutdruckes während einer Pferdeanästhesie ist sehr wichtig um die Sicherheit des Patienten zu garantieren und das Anästhesiemanagement zu optimieren. Ein mittlerer Blutdruck von mindestens $60-70 \mathrm{mmHg}$ sollte aufrecht erhalten werden, damit die Perfusion des peripheren Gewebes nicht beeinträchtigt wird was zu Myopathien führen kann. In vielen Pferdekliniken gehört die invasive Messung des arteriellen Blutdruckes (IBP) mittels Katheter in peripheren Arterien während einer Pferdeanästhesie zur Standardüberwachung der Anästhesie, obwohl die Genauigkeit dieser Messung nie belegt wurde. Vor allem auch, wenn der artielle Blutdruck bei Forschungsprojekten gemessen wird, wäre es wichtig zu wissen, wie genau diese Messungen in verschienen Arterien sind, insbesondere in Arterien, die sich weit entfernt vom Herzen befinden. Pferdekliniken, welche auf eine Überwachung des Blutdruckes während der Anästhesie gänzlich verzichten tun dies meist, weil die invasive Messung als zu kompliziert empfunden wird und das Setzen eines intraarteriellen Katheters zu viel Zeit in Anspruch nimmt. Die Messung des Blutdruckes mit nicht invasiven Mitteln ist einfacher und geschieht bei modernen Systemen automatisch. Schon heute finden diese Systeme vereinzelt bei Operationen im Felde, kurzen Eingriffen oder bei Fohlen ihren Einsatz. Verschiedene solcher Monitoren wurden bereits bei Pferden untersucht, konnten aber keine befriedigenden Ergebnisse liefern.

In der voliegenden Studie wurde bei sechs Ponis unter Sevofluranästhesie in Seitenlage mit Infusion einer Kochsalzlösung oder mit Dexmedetomidininfusion (jedes Pony wurde zweimal anästhesiert) der invasive Blutdruck in $\operatorname{der}$ A. fazialis und in $\operatorname{der}$ A. metatarsalis gemessen und mit dem Blutdruck in der A. karotis verglichen. Gleichzeitig wurde nicht invasiv mit einem neven Monitor (Sentinel) über der Schweifarterie, den beiden Medianarterien oder der Metatarsalarterie der Blutdruck indirekt gemessen und ebenfalls mit dem Blutdruck in der Arteria Karotis verglichen. Die nicht invasiven Messungen erfolgten in zufälliger Reihenfolge, eine Stelle nach der anderen. Die Größe der Blutdruckmanschetten betrug 40-60\% des Umfanges der Stelle an welcher gemessen wurde. An jeder Stelle wurde viermal hintereinander gemessen und die jeweiligen Werte mit den zur gleichen Zeit in der Arteria Karotis gemessenen Werten verglichen. Alle gemessenen Blutdrücke wurden mittels Bland Altman-Analyse mit dem A. karotisDruck verglichen. Die Übereinstimmung von wiederholten Messwerten, das heisst der Messfehler, wurde ebenfalls ermittelt.

Die nicht invasive Messung mit dem Sentinel war je nach Messort im Mittel in 73.9-92.3\% der Fälle erfolgreich. Die Erfolgsrate der Messungen an den verschiedenen untersuchten Messorten im Vergleich zur Anzahl erfolgter Messungen ist in Tabelle 1 dargestellt. Die Resultate der Bland AltmannAnalyse sind in der Abbildung 1 dargestellt. Die untersuchten Spannweiten der Blutdrücke waren in der Gruppe ohne Dexmedetomidin Infusion größer als mit Dexmedetomidin (Abbildung 2).

Die systematische Messabweichung war grundsätzlich mit der nicht invasiven Methode größer als mit den invasiven Messungen und die Übereinstimmung mit den invasiven Messungen besser. Die nichtinvasive Messung über der Schweifarterie zeigte die beste Übereinstimmung bei wiederholten Messwerten und auch die beste Übereinstimmung mit dem Karotisdruck insgesamt. So betrugen bezüglich indirekte MAPmessung an der Schweifarterie die Übereinstimmungsgrenzen $15.3 \pm 8.2 \mathrm{mmHg}$ (mit Kochsalzlösung) bzw. 13.3 $\pm 11.6 \mathrm{mmHg}$ (mit Dexmedetomidin). Während Dexmedetomidininfusion war die Messung von MAP und DAP in der A. fazialis und der A. metatarsalis nicht verschieden. Der SAP hingegen zeigte eine deutlich höhere systematische Messabweichung sowie weitere Übereinstimmungsgrenzen im Vergleich zum Karotisdruck.

Zusammenfassend muss gefolgert werden, dass die nicht invasive Blutdruckmessung über der Schweifarterie mit dem neuen Monitor Sentinel für die Pferdepraxis eine mögliche Alternative zur invasiven Blutdruckmessung darstellt und sicher besser ist, als wenn der Blutdruck nicht gemessen wird. Sowohl die Metatarsal- als auch die Fazialarterie zeigten eine akzeptable Übereinstimmung mit der Blutdruckmessung in der Arteria Karotis. Einzig der SAP in der Metatarsalarterie zeigte eine recht hohe systematische Messabweichung und überschätzte die von der Karotisarterie gemessenen Werte, was zumindest bei Forschungsprojekten bedacht werden muss. 